\title{
Reconceptualization of Gender Relations in Saeed's Amal Unbound and Rao's Girls Burn Brighter
}

* Dr. Muhammad Asif (Corresponding Author)

** Nimra Zafar

*** Tahreem Iftikhar

\begin{abstract}
This study examines gender relations in Saeed's 'Amal Unbound' and Rao's 'Girls Burn Brighter. The basic aim of this study is to review the existing patriarchal norms that exploit women. This comparative analysis seeks to offer a postmodern feminist worldview by redefining and reconceptualizing women's status, explaining their strengths, and granting them subject status. This study questions the concepts of rationality that perpetuate normative gender stereotypes and demands a brand new way of conceptualizing truth by breaking down the categories. It challenges the authorities, stereotypes, icons, and sexist values. Both texts that are examined in this study are set in the backdrop of the socio-cultural milieu of Pakistan and India. By presenting the cultures of two different countries, an effort has been put in to reconsider gender relations as a means of resistance. It reflects on the relationship between women and the environment and recognizes women's steadfastness in the face of oppression. Furthermore, an attempt has been made to undo patriarchal male coercion and explore the reasons for the continued proliferation of conscious and unconscious objectification of women.
\end{abstract}

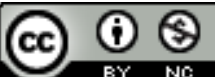

Keywords: Gender, Subject, Resistance, Oppression, Autonomy

Introduction

This study argues that women can discover themselves through agency and autonomy by challenging and undermining patriarchal structures that have subjected them to submission leaving no room for resistance. Gender relations reflect an imbalance of power that is constructed by discursive practices and social norms and need to be recontextualized and revised to ensure a fair and just society. Both the novels selected for critique in this research argue for challenging patriarchy and asserting women's agency.

Amal Unbound (Aisha, 2018) by Aisha Saeed is a story of a young girl who fights against the patriarchal society boldly. Feudalism and poverty are her nemeses. Despite all odds against her, she does not relent on her education and personal growth. She is not a radicalized rebel who goes all guns blazing against the patriarchy, rather she fights her way through the circumstances and makes her way till she asserts herself defiantly and wins finally, giving a message of hope to all the young girls especially showing how to survive in a society that muzzles you.

Girls Burn Brighter (Rao, 2018) by Shobha Rao is a travail of two young girls who are subjected to physical, sexual, and psychological abuse and are victims of trafficking. Their stories expose cultural misogyny with its perversity that condemns women to a life of drudgery and abject subjugation. Girls Burn Brighter as a whole is a story of helpless women who have no role or place in society.

Postmodern feminism considers gendering a discourse that is not natural. Gender is constructed through social and cultural practices that privilege patriarchy and treat women as others. Moreover, patriarchy works differently in different conditions depending on social and cultural conditions, and the status of agency employed by women. The white women are in a much-privileged position compared to underprivileged and deprived African women. Intersectionality then deals with multiple layers and levels of social and cultural categories to identify social and cultural practices that discriminate against women and victimize them. Postmodernism rejects modern feminism's focus on

* Government College University, Faisalabad Email: masifshafii@gmail.com

** University of Jhang, Jhang Email: nimrazafar918@gmail.com

*** University of Sargodha, Sargodha Email: tahreemiftikhar101@g mail.com 
gender denying the differences that exist within the genders. Liberal feminism privileges western values and concepts like individualism and autonomous self. Postmodernism rejects western normative concepts that ignore the alterity. Gender inequality is seen within the framework of inequality in power relations. Thus postmodern feminism focuses on how gender inequality is naturalized in discourse.

Postmodern feminism is vital for analyzing social and cultural mechanisms that normalize women's oppression and subjugate them as objects. Judith Butler (1990) focuses on gender and its performativity. She challenges and rejects conventional gender representation. Her views on the performativity of gender have radicalized feminism. She considers gender a linguistically constructed and socially imposed category that depends on the distinction between genders (Butler, 2009).

In postmodern feminist theory, a binary-based dichotomy, which prevails in society, is questioned. Conventional conceptions of manliness and patriarchy contribute to women's oppression. There is a dire need to re-conceptualize gender elements and examine connections between men and women in society in a new way. Restoring gender imbalance is not easy and remains a goal that feminists dream to achieve can be possible only through a thorough revision of gender roles and constructions.

\section{Literature Review}

A brief outline of research already conducted from a feminist perspective will familiarize the reader with the gender issues and that are contextualized in various types and forms of feminism.

Sasha Roseneil (2000) in the Art of the (I'm) Possible) contends that postmodern feminism is trapped in philosophical abstractions ignoring the sociological issues that are of practical concern for this purpose. She privileges feminist sociology that focuses on the analysis of social, cultural, economic, and political practices. Postmodern feminism in her opinion is anachronistic as postmodernism is apolitical and ahistorical by default. She also supports cultural feminism that transforms the category of woman. (Roseneil, 2000). Roseneil raises a very pertinent question when she raises stakes against the stereotypical binaries that confine and chain women.'Can citizenship transcend the gendered dichotomies on which it has historically rested: between public and private, reason and emotion, the cognitive and the embodied?' (Roseneil,2013, p.2)

Rosi Braidotti says that gender politics is disconnected in a social sense. Women advocacy is supplanted in regulatory settings by the less fierce framework of institutionalizing sexual identity (Braidotti, 2005). The post-feminist development is giving way to pseudo connections of sexual identity in the culture at large. Within the developed nations, undoubtedly, women are the washouts of the present mechanical innovations. On the subject of historical amnesia, post-feminist neo-liberalism may be a distinction in that it communicates to other ladies the dismissal of the sense of collective affiliation. Its characteristic highlights are the following: to begin with, it considers budgetary triumph or status as the sole degree of females' position. As cash alone is taken as the suggestion of flexibility, social disillusionment is legitimately seen as a need for liberation. Besides, in line with neo-liberal standards, it celebrates around the world as the motor of women's advancement.

Braidotti (2005) contends that after modernism new master narratives have emerged that privilege determinism. New technology and market forces have created new fatalism that left no room for freedom or autonomy. She believes in this backdrop, the feminists should seek a complete transformation of subjectivity that is based on new epistemology and reconfiguration of discourse that privileges positive terms for constructing a new female subject. As Asberg and Braidotti (2018) say 'feminist post-humanities aims to discover our rhizomatic and multi-directional entanglements with each other. It points to a multitude of people, technoscience, global media, biotics, ecologies, animals, finance, land, and other lively matters for consequential but non-teleological purposes of story-telling in feminist scholarship'. (Asberg and Braidotti,2018, p15).

1980s postmodernism provided a viable theoretical alternative to existing discourses. Where pre-postmodern second-wave feminism subscribed to prescriptive notions of what a woman should or should not be, postmodern feminists (or post-feminists) instead articulated a much more diverse, malleable, morally and culturally relative notion of what it means to be a woman. This new relativist approach meant that feminists were now making a conscious effort to engage with third-world women in a way that acknowledged cultural particularities. Today Muslim women are struggling to find a place for themselves. Western feminists have the potential to play an important role in the process of change in the Muslim world. The nature of this role has yet to be determined. In recent decades, 
Western feminists have tended to superimpose their own culturally specific notions of equality on the Muslim world. Now, there is the risk that a new generation of postmodern intellectuals will decide to slowly disengage. With this in mind, finding the middle ground has never been more urgent.

Hamid (2006) calls for reviewing and renewing feminism in Muslim societies in their epistemological context and rejecting the notion that Islamic feminism is an oxymoron. He contends that Islam is different from other religions. Hence, Islamic societies should not be measured by western standards which are Christian in origin and nature. As Islamic societies follow the political model of Islam, they cannot follow the western systems. The same is the case with feminism. He argues that postmodern feminism argues for a diverse and culturally relative approach to what it is to be a woman. The problems faced by Muslim women should be viewed in the ir cultural contexts and any attempt to impose western feminism on Muslim women can backfire. As he says 'I do not believe that the West should remake the Middle East in its image. Rather, I believe that, because the notions of freedom, equality, and women's rights are universal, they can be re-interpreted and articulated in ways that recognize the importance of cultural context.' (Hamid, p.82)

Parapart (1993) argues that in western feminism, the concept of 'other' has emerged from the writings of the white middle-class women writers who based their generalizations about 'other' that is the third world women, black and Latino women on their own experiences. Postmodernism has provided these women of the third world with tools that have enabled them to project their cases in their contexts and their voices. As Parapart says 'the postmodern focus on difference has offered ammunition to women who felt excluded'. (Parapart,1993, p.5)

\section{Theore tical frame work}

Judith Butler (2002) contends that like self, subject, and gender body is also historically constructed and constituted. She questions the category of distinct sexes and argues that bodies are a matter of historically layered and sedimented practices and performances. 'The effect of gender is produced through the stylization of the body and, hence, must be understood as the mundane way in which bodily gestures, movements, and styles of various kinds constitute the illusion of an abiding gendered self". (Butler, 2002, p.102). This sets the context for Butler's concept of performativity. Butler considers language a vital tool in the construction of gender and talks of gender scripts as if gender is a text. She rather focuses on gender roles as rehearsed by performative subject and not the given sex category. In this way, she questions and rejects the essentialist set of traits and characteristics of women. Thus she believes that sex is socially built. Butler (1993) believes that treating gender and sex in simplistic terms and from a limited perspective has resulted in binarism interpretations of terms which undermine the complexity and variety that these categories inhere in practice. As she says "subject is constituted through the force of exclusion and abjection" (Butler, p.85). Diversity of opinions can help shape a better understanding of the various performative roles of genders. Diversity, multiplicity, and difference should characterize gender discourse. Opening up space by privileging gender performativity is what can emancipate gender from limited categorization. As she warns "within subjection the price of existence is subordination." (Butler, 1997, p.75)

Deconstruction provides important tools to feminism to deconstruct and debunk essentialist stereotypes and myths that entrap women and render them hostage to cyclic narratives that leave no room for agency them. Glass (2004) states that the deconstructive approach when embedded in postmodernism allows for rejecting the narratives of vulnerability that are so ingrained in grand narratives of patriarchy. (Glass, p.93)

Jon (2020) strongly supports imbuing feminism with antifoundational postmodern tenets that disrupt and reject 'objective', 'transcendental', or 'the right' knowledge. This approach makes it possible to problematize the patriarchal episteme that privileges males over females. In her opinion, participatory approaches that focus on shared experiences and wisdom are of great significance. (Jon, 2020, p.150)

Helene Cixous (1980) argued for developing feminine writing which she considered vital for female consciousness. According to her, female writing has the potential of subverting patriarchal social norms and society. Women can write themselves in their idiom and in this way they will not be dependent on male discourse. She goes on to say that women must rewrite history and recover their role and place in society that has been suppressed by phallocentric history. "Write! Writing is for you, you are for you; your body is yours; take it," (Cixous, 1980, p. 246). In her opinion without changing the cultural system no tangible progress towards women's emancipation is possible. 
Chandra Mohanty (1991) advocated the cause of third-world women by challenging their stereotypical representation and objectification in western feminist discourse. She objected to the presentation of third-world women as uniformly poor, powerless, and vulnerable. She is very critical of western colonial narratives that 'besides being normed on a white, Western (read progressive/modern) / non-Western (read backward/ traditional) hierarchical, these analyses freeze third world women in time, space and history. (Mohanty,1991, p.6)

\section{Analysis}

This is a postmodern feminist analysis of Aisha Saeed's Amal Unbound (2018) and Shobha Rao's Girls Burn Brighter (2018) in the light of Judith Butler and Helen Cixous's postmodern feminist theories. The researchers have investigated the complex social and cultural norms and practices that characterize female characters living in a postmodern world. The writers in both novels present female characters who find themselves trapped in a vicious circle of poverty and helplessness and the only way they can come out of it is by revolting against the system that keeps them subjugated.

\section{Essentialism and Gender roles}

Gender roles and relations are validated in soc iety by men. Women are understood to live agreeing to that characterized structure in which their parts are already characterized. Girls Burn Brighter portrays an Indian rustic society in which women happily comply with the roles assigned to them by patriarchy. Poornima who is married to an individual whom she does not like is expected to live quietly with her in-laws. The same is the case with Amal in Amal Unbound who was a rustic young woman and who was forced by her father to quit her studies to take care of her parents and siblings.

Rao (2018) highlights the culture of India in which man only requires spouses for the housework. However, Poornima continuously thinks that in case she got reasonable fair skin "her father might've found a better match for her: someone who wanted a wife, not an ox" (Rao, p.13). Ladies with reasonable skins get great matches for their marriages but women with conventional and dim skins are continuously considered to be an edge. They get married, in case they can perform in the family and fields well. Poornima, throughout the novel, faces embarrassment because of her color and figure but this shame does not make her weak but strong enough to handle all the brutality with courage.

Women are not permitted to do anything that is thought to be against values and which can devalue the image of the family. They are supposed to remain at home to take care of houses. Saeed displayed a primitive framework of a rural society in which women are not permitted to do anything against the wish of their feudal master. Amal, the protagonist, of the novel Amal Unbound had to serve within the house of Jawad Sahib and her father never helped her to get out of the unsavory situation. Parents wish that if a son were born, he would be the breadwinner of the house. They invest in the education of boys and fulfill their wishes and dreams. Amal was entrapped in institutions of such a society which were established by the men surrounding her. As when she went to market her mother said "your father doesn't like you going to the market by yourself" (Saeed, 2018, p.29).

\section{Reconceptualization of Gender Re lations}

Both Rao and Saeed have significantly questioned the present condition of society. They present the characters of girls who no longer go by the prevailing norms rejecting norms as a building block of their fate. They are brave and capable of taking postmodern feminis m's stance. Both writers query and reject typical essentialist practices and normative roles assigned to women in society. The female characters assert their agency and represent resistance through the performativity of resistance in their words and actions. Both these works are commanding representations of these manifestations within postmodern feminism via numerous categorized characters. These characters signify that women in society preserve their selves but cannot go against the world of abuse and infringement.

In her bestselling book, Rao takes up the task of depicting different women confronting numerous issues from roadside savagery and household viciousness to patriarchal social orthodoxy. Girls Burn Brighter highlights the injustice against women in the world. It is the story of the unbreakable bond between two young ladies. This bond makes them solid enough to have an independent life. This novel is placed in India and America. The friendship among girls enables them to discover their selves in a tormenting world. Rao uses the symbol of Charkha in the novel to show the quality of female characters. As Poornima who was born in a destitute family where a girl is considered a burden, and she has to spin Charkha to feel glad -- "each spool of thread sometimes red, sometimes blue, sometimes silver, and this seemed like a fortune to her" (Rao, 2018, p.7). Charkha is 
an image of women's strength and independence. Charkha gives her such comfort and joy as she has never felt it before. The spinning of Charkha can be considered as the position of postmodern feminist approach that time has changed presently and a woman must alter the accounts and traditions of society

Amal Unbound is a beautiful and moving tale by Saeed which portrays brave and powerful girl Amal who strives to become educated while battling the patriarchal and feudal society in which she lives. Like Rao, Saeed additionally uses symbols; one of the most important symbols is Pomegranate. Pomegranates are used as a sign of hope or self-respect for Amal. Amal likes pomegranates much. Saeed additionally uses it to represent women's empowerment as Amal refuses to give the pomegranate to the Jawad Sahib who is the feudal lord. When Jawad Sahib hits her with the car and picks up her pomegranate, Amal's thought was "But all I could see was the red pomegranate and how he grasped it in his palm as though it was already his" (Saeed, 2018, p.50). She grabs the pomegranate from Jawad's hand because she couldn't believe that he had more control over her. This act indicates that she will not, in any conditions, jeopardize her self-respect. Her father's reaction to the whole incident shocks her. As her father owes a debt to Jawad, he asks Amal to apologize to him. 'I don't care if he wanted your entire satchel of things-my father snapped. You give it to him. You drop everything into his feet. Apologize and walk away" (Saeed, p.55). Her father was very helpless in front of Jawad "Don't you have any idea the lengths that family goes to just to satisfy their egos?" (Saeed, 2018, p.55).

Savitha is the second most significant character introduced by Rao, who fights poverty at a young age. She needs to raise money to feed her family. Rao stresses that a man is not just a gender who considers himself to be the family's breadwinner; it can also be a female. According to Savitha, "I could make us more money" (Rao, 2018, p.16). Savitha is a very assertive and determined figure who firmly opposes the harassment of boys from Poornima's street. Savitha's strong character can be seen when she does not let herself be intimidated by the boys. She holds firmly on Poornima's hand and says "don't look down, look up" (Rao, 2018, p.25). After rejection from a family, Poornima was beaten by her father; however, Savitha proves her strength. Savitha advises her via her story of an Elephant who was once overwhelmed by a little crow. Rao once more presents an image of an Elephant to exhibit the male-dominated society. By offering this story Rao's essential purpose is to demolish the norms as Savitha states "Understand this Poornima: that it's better to be swallowed whole than in Pieces, only then can you win, No elephant can be too big, only then no elephant can do you harm" (Rao, p.54). Women ought to have the courage to keep their selves; Savitha is the character who gives conf idence to Poornima as not to be afraid of the patriarchal system. Like crows, women can demolish and crash the effective and hegemonic patriarchal system by challenging its conventions. It is as if it were women who can make themselves amply courageous to confront all the brutalities by standing against and pulverizing all those faith systems which are detrimental to her presence. Like Rao, Saeed also reconstructs the gender relations between women; she additionally depicts the genuine bond between a teacher and a student. This bond between girls gives brilliant power to them. Amal, usually eager to understand the entirety of earth, longs to recognize the hidden truths. Amal's teacher additionally proves to be a strong personality that becomes an inspiration for Amal as the latter says, "Write about what you see! Write about your dreams, Pakistan was founded by the dreams of poets. Aren't we of the same earth?" (Saeed,2018, p.5). Saeed also focuses on the relation between Omar and Amal as Omar is very supportive of Amal. Living in a Pakistani rural society where the friendship between a girl and a boy is no longer allowed, Amal used to meet him secretly because Omar regularly gave her books to read including Ghalib. So their bond becomes strong. Postmodern feminists say that women ought to face patriarchs with courage and need to be strong enough to speak against the injustices that they face at every level in the ir lives. Rao asserts that it is not the only man in whose company a female can feel safe. Time has changed now. If a woman can understand her worth and has the support of other girls she can do anything she desires. As Poornima says, "All we had to do was stand closer. Stand together. As if, against rain, aga inst fate, against war, two bodies, the bodies of two girls, were greater than one" (Rao, 2018, p.319). Here Rao supports Cixous's point of replacing patriarchy with matriarchy as she advocated the superiority of a woman over a man. In the same sense, Poornima feels that nothing can save them but only themselves. 


\section{Titles of the novels deconstruct essentialisms}

Rao and Saeed present female characters from ordinary societies. They want women to write for themselves and lessen the intensity of binary language. Their characters to the poor sections of society. They are subalterns who otherwise cannot speak. They are ignored and victimized. They are considered no more than domestic slaves, or unwelcome guests. They assume importance as incubators, as a means of producing the males (sons); contrary to which they lose importance. A male breeder is preferred, though temporarily, to a female breeder. Most of the writers write about females from high society. Virginia Woolf once claimed that History seldom acknowledges the vaguest trace of an aboriginal woman. The middle-class girls, with plenty of knowledge and integrity at their disposal, must have contributed to many of the splendid revolutions. But women never earn an accolade from historians, rather they are absent in history books. Rao and Amal depict the characters that are not according to the normal essentialism; rather they go against them. Titles of both novels signify the rejection of the essentialist construction of women. Girls burn Brighter signif ies an entire realm of female ambition; how they wage a silent war against authoritarian communities. Burning means the capacity to burn with intensity as the female who is portrayed in this novel wriggle out of various domestic, physical, and social abuses. All these obstacles fail to break their shins, and the embers under the ashes remain alive. In a society, like that of India, where a girl is supposed to be the property of a man, who remote-controls her domestic and public actions, Poornima and Savitha are determined not to be dictated by the ir male counterparts. They take the reins of their destiny into their own hands so that they do not die the death of a commoner. They project themselves as the astonishing models of efficiency in the most appalling situations. The title of the novel Amal Unbound is extraordinary as Amal is not bound to or dictated by any system. She defies the system she was once a part of - an ordinary cog. But then she fights against the odds of circumstances and pursues her glorification, oblivious to the consequences. Amal does not care about the strict structure of society around her. She struggles to obtain her aim with determination. She discovers herself in this fight and this sense of discovery further strengthens her to face the shackles of society. The social setup she was dwelling in does not expect anything from a woman but to be extremely compliant. She breaks the shackles of male domination by fighting against the unnerving do's and taboos of male chauvinistic society.

\section{Destabilizing tradition and universal truths}

The relationship between postmodernis $m$ and feminis $m$ is not confined only to the first world but to the third world as well. Postmodern Feminism encourages replacing patriarchal society with meritocracy. Poornima's idea is to envis ion and assemble a world with an exclusive economy, human interactions, and language for girls. Poornima recalling a past incident in which she had to apologize to the landlord at the behest of her father says, "It was absurd of me. It was coward of me. I shouldn't be asked for forgiveness when I'm not even sure I had anything to do w ith it" (Rao, 2018, p.120). Rao justifies Butler's concept that women cannot be seen as homogenous because women are in different subject positions in different parts of the world. Due to numerous specific distinctions like race, rank, position, and ethnicity, they cannot be regarded as a united group. Butler raises her voice against the current trend among feminists of defining women in various categories; rather she contends that the way power functions and shapes concepts of womanhood should be focused. Butler calls for reconceptualization of subjectification, signification, and agency vis a vis woman. Butler also posits intentionality, self-reflexivity, and autonomy as some of the tools that emancipate women. Butler believes that feminism should call for the social transformation of gender relations.

Poornima's struggle typifies Butler's quest for the emancipation of women through social change. She fights for her survival in the same house and then leaves the house to find Savitha. After leaving home she is sold to a brothel, where she carries on the flesh trade just in hope of finding Savitha. Rao deconstructs the conventions by building a gender relation between Mohan and Savitha. Mohan who used to molest the purchased girls had developed a connection with Savitha. "You are an empire. You're more than an empire" (Rao, 2018, p.257). Contrary to traditional approaches and norms, she does not accept her fate. She is not one of these females who consider their destiny already fated, instead, she refuses to accept it.

Cixous contends that women need to write and speak in their very own feminine style using unconventional style rejecting traditional syntax and masculine language. According to Cixous, women can assert their voice and agency by rejecting phallocentrism and writing can be potently 
instrumental in it, as she says 'Writing: sway of leaving no space for death, of pushing back forgetfulness, of never oneself be surprised by the abyss' (Cixous, 1991, p.7). Amal raises her voice in opposition to the feudal lords. Her courage can be estimated when she stops the police from entering the residence of Jawad Sahib. She used to choose her lifestyle while living in that house. Saeed presents gender roles are defined via man, as Butler argues that gender need not be conceived as a sustainable organization; instead, individuality is obliquely installed in the period, fashioned in herbal surroundings. On this issue, Butler argues that gender truly shouldn't be deemed a constant identification; however, it is created and generated over time by a set of regularly occurring presentday gestures. So, Amal's identification is what she used to be doing there. Amal desires to stand in opposition to that system where she feels misfit. Amal did not want to accept everything there "but why was that a reason to just accept everything and go along with it?" (Saeed, p.146). Her sense of helplessness overwhelms her when she returns to her father's home. She is bruised, broken, and shattered. She has been humiliated and vilified. She is hurt and injured. She says: "Strong? What did it mean to be strong? Did I have any other choice?" (Saeed, 2018, p.158). however, despite all this, Amal proves herself a woman with spark and provides a ray of hope for other women. She proves her strength of mettle when gets Jawad arrested for murdering a man. It is very stunning that a maid with no strength at all becomes strong enough to stand up against her landlord and get him arrested. She fulfills Cixous's prophecy and acts out her strategy: the female texture overwhelms the masculine in that it consists of two dominant layers: the legislative problems of wish and the poetics of provider. She demands that girls ought to write their bodies i.e. their writing ought not to be subversive, taking a defensive stand against the mastery of patriarchy, but deep down their self-reflexive and selfassertive natures, the contrapuntal combination lurks that can be portrayed as "prospective inscape". Amal musters up all courage and tries to end Jawad Sahib for his brutal and corrupt actions as she additionally agrees with Bilal and Nabila "But what if we could do something? What if we at least tried to stop him?" (Saeed, 2018, 206)

Cixous sets out a postmodernist feminist culture. By adopting a rather Lacanian approach, she surely broadens the scope of Unconscious, giving it the strength at work and the being of the self. So is stated by Amal as Saeed in the novel says "If everyone decided that nothing would change, nothing would ever change"(Saeed, 2018, p.207). Nothing scares Amal as she is the real heroine of the story and sets an example for many girls who are unprivileged and deprived of rights. Amal was free and Jawad was arrested. Amal is the persona that helps Cixous point of giving up patriarchy for the final time. Cixous' concept is forcefully communicated when she asks to smash the patriarchy, not to alter it, unw ind or supplant it with matriarchy. Amal is at ease and free and nothing should make her afraid anymore as she comments at the end of the novel, "But I didn't feel afraid. Today I was free, and even if I did not know what the future held.... And right now, at this moment, this was enough" (Saeed, 2018, p.226). Both Rao and Saeed have addressed the existing circumstance of society. They display the characters of girls who do not accept the prevailing standards as essential requirements for their destiny. The question, challenge and try to overturn the patriarchal structures and system. This research demonstrates that narratives of resistance that empower women can play an important role in radicalizing women and promoting their agency.

These two literary works are narratives of gender resistance and show that women can chart their destiny through determination and courage. Without challenging the patriarchy and rejecting its discursive practices, women cannot hope to liberate themselves from the clutches of societies. Norms, customs, taboos, and rituals will continue to silence and subjugate women as long as women continue to accept everything as natural and fated. Postmodernist feminism shows the way forward by highlighting the role agency and signification can play in empowering women as individuals. As this research shows women when they speak up they have listened and they can be the masters of their fate if they act boldly.

\section{Conclusion}

This research shows that women pass through many trials and tribulations in the ir daily lives to live what otherwise would be a normal life. Women can change their role in life by be ing proactive and making all the ir decisions themselves. Submitting to the patriarchy and hoping that everything will be normal will only perpetuate existing suppression and repression of women. Resistance is the keyword. The study questions the concepts of rationality that result in essentialism of gender roles and argues for another way of conceptualizing gender by breaking down the categories. It challenges the 
authorities, stereotypes, symbols, and sexist values. Females characters in both the novels examined in this research reject essentialis $m$ in society by showcasing procreative destabilize patriarchal system by destabilizing the system from within. This study destabilizes the set notions of patriarchy and essentialism. Paradigmatically, women go outside the typical roles focusing upon their needs and goals by negating the oppressive system. The study shows that postmodern feminism creates a space in which women can inscribe resistance against the patriarchal norms that engender gender inequality. Postmodernism presents women by differences and not similarities. As the postmodern feminists contend that gender is constructed through language and language is inescapable, it can be deconstructed only through language that replaces masculine syntax with feminine one. This research has great implications for the women seeking to find their way out of the preponderance of phallocentrism by asserting their rights and exerting their energies in the right direction.

\section{References:}

Asberg, C., \& Braidotti, R. (Eds.). (2018). A feminist companion to the posthumanities. Springer.

Braidotti, R. (2005). Critical cartography of feminist post-postmodernism. Australian Feminist Studies, 20(47), 169-180.

Butler, J. (2002). Gender Trouble: Feminism and the Subversion of Identity, London: Routledge.

Butler, J (1993). Bodies that Matter, London: Routledge.

Butler, J. (1997) The Psychic Life of Power: Theories in Subjection, Stanford: Stanford University Press

Cixous, H. (1980b). The Laugh of the Medusa. In E. Marks \& I. de Coutivron (Eds.), New French feminisms: An anthology (pp. 245-264). Amherst: University of Massachusetts Press. Flax, J., (1987). Postmodernism and Gender Relations in Feminist Theory', Signs Vol. 12 (4), p. 62143.

Cixous, H. (1991). " Coming to writing" and other essays. Harvard University Press.

Glass, N., \& Davis, K. (2004). Reconceptualizing vulnerability: Deconstruction and reconstruction as a postmodern feminist analytical research method. Advances in Nursing Science, 27(2), 82-92

Hamid, S. (2006). Between orientalism and postmodernism: the changing nature of western feminist thought towards the Middle East. Hawwa, 4(1), 76-92.

Jon I. Reframing postmodern planning with feminist social theory: Toward "anti-essentialist norms." Planning Theory. 2020;19(2):147-171

Mohanty, C. T., Russo, A., \& Torres, L. (Eds.). (1991). Third world women and the politics of feminism (Vol. 632). Indiana University Press

Parapart, J. L. (1993). Who is the 'Other'? A postmodern feminist critique of women and development theory and practice. Development and Change, 24(3), 439-464.

Rao, Shobha. (2018). Girls burn brighter, Newyork: Flatiron books.

Roseneil, S. (2013). Beyond citizenship? Feminism and the transformation of belonging. In Beyond Citizenship? (pp. 1-20). Palgrave Macmillan, London.

Saeed, Aisha (2018). Amal Unbound, Newyork: Nancy Paulsen Books. 